\title{
AACSB Accredited Business Programs: Differences And Similarities
}

Charles P. Corcoran, (Email: Charles.p.Corcoran@uwrf.edu), University of Wisconsin, River Falls

\begin{abstract}
Under AACSB "mission driven" standards, three tiers of business programs have emerged: doctoral level, master's level and baccalaureate level. AACSB institutions in these three tiers are significantly different in many respects. Given that institutional differences are so large and widespread among the three tiers, what, then, are the characteristics, if any, which give AACSBaccredited programs a common identity? Evidence is presented that faculty perceptions are quite similar, regardless of program tier. Thus, the common bind of these diverse programs is measured less in terms of resources and more in terms of a shared ethic of mission-driven excellence.
\end{abstract}

\section{INTRODUCTION}

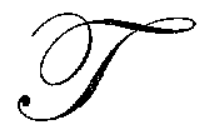

he Porter and McKibbin (1988) report entitled, Management Education and Development: Drift or Thrust into the $21^{\text {st }}$ Century, marked a watershed in redefining the appropriate role of higher education in business. Porter and McKibbin concluded that the business education paradigm is too theoretical. Changes in curriculum, research with attention to addressing practical business problems, and a new emphasis on business community relations were a few of their suggested changes.

At about the same time, the Association of Collegiate Business Schools and Programs (ACBSP) was created as an alternative to AACSB. This was possibly viewed as a threat to the monopoly AACSB enjoyed as the sole accrediting body for business schools. As Ramey (2001) observed,

The external threat of ACBSP and that organization's push to serve the 400 to 500 non-member schools, and possibly reach member non-accredited schools, could definitely erode market share, hence market position, in a way that AACSB could not ignore. The need to survive always brings change a little faster.

In reaction to these concerns, the AACSB initiated a new set of standards that were fully integrated into the accreditation regime by 1994. The major change in the new standards was that they were "mission driven." Under the new standards, each institution seeking either first time accreditation or reaccreditation would establish a mission statement that reflected "excellence" for a school of their stature. The institution is then assessed with respect to its success in meeting the objectives of its stated mission.

As the number of accredited business schools continues to proliferate, with the number of accredited institutions increasing by about $300 \%$ since 1970 , can excellence really be achieved in all 452, and counting, member institutions within the three levels? Is there a tacit sense that "mediocre" may be supplanting "excellence?" While no institution would advocate a mission statement heralding, "a mediocre faculty, teaching mediocre students, who get mediocre jobs," some observers admonish this possibility (Yunker, 2000; Jantzen, 2000). Argenti (2000) notes the danger of brand proliferation. At the current pace of accrediting new programs, it's become less an issue of the credibility conferred by accreditation and more an issue of why an institution is not accredited. Status will have to come from other venues such as admissions selectivity, grants availability, and faculty research (Van Auken, Cotton, McKenna, and Yeider;1993). Program rankings have already usurped accreditation for the better programs (Gioia and Corley; 2002). 
Leading programs may not only question the value of accreditation, but may also take umbrage with how lesser institutions have leveraged their common AACSB affiliation for personal gain. Michigan Technical University, for example, promotes its AACSB accreditation in these terms:

The School of Business and Economic's programs have been judged equal to accredited programs such as the University of Michigan, Harvard University, Stanford University, and Northwestern University (2004).

The post-1994 intellectual contributions requirement respects an institution's mission, although it remains somewhat prescriptive:

Schools with a strong emphasis on graduate programs, in particular those with a strong commitment to doctoral programs, should have a substantial emphasis on basic scholarship. Schools with a predominant emphasis on undergraduate degree programs may have the emphasis of their intellectual contributions in applied scholarship and instructional development. Schools with a mix of undergraduate and graduate programs, without doctoral programs, may have a balance among basic scholarship, applied scholarship, and instructional development (AACSB, 1991).

The intellectual contributions requirement is essentially unchanged from the pre-1994 standard for institutions with a mix of undergraduate and master's-level graduate programs. The requirements are greater for doctoral granting institutions and they are lesser for schools with a predominant emphasis on undergraduate programs, compared with the pre-1994 standard.

The AACSB has thus created a de facto "tiering" scheme based on research productivity. While earlier standards required all institutions to meet a single set of research objectives, the new standards establish three levels of research expectations. McKenna, Cotton, and Van Auken (1997) assert that we should move away from a classless model and codify these large distinctions in expected research productivity among the three tiers.

This research begins by exploring criteria other than research in order to determine if, as is explicitly acknowledged for research, there are demonstrable differences among institutions in the three tiers.

\section{METHODOLOGY - MEASURING DIFFERENCES AMONG INSTITUTIONS}

A number of criteria were measured in terms of mean values for institutions within the three tiers: doctoral institutions $(n=34)$, master's level institutions $(n=35)$, and undergraduate-only institutions $(n=10)$. Of the 452 institutions presently accredited, 105 confer the doctor degree, 316 confer the master's degree as their highest degree, and 31 grant only a bachelor's degree. The 79 institutions in this sample were chosen randomly, although substitutions were made in several instances due to unavailability of information for originally selected institutions. Testing for mean differences (at the .05 level of confidence) among institutions in the three tiers was achieved with the t-test for samples with independent means. Criteria measured include:

- GMAT scores (not applied to the undergraduate institution tier)

- $\quad$ Percent of faculty with doctorates

- Number of full time faculty

- Size of operating budget

- Number of degree programs

- Number of graduates

- Undergraduate tuition

- Graduate tuition

Data for GMAT scores was found in the Guide to Graduate Business Schools (2004). All other data were found from the AACSB International 2001-2002 Business School Questionnaire (2002) or from institution web sites. 


\section{FINDINGS - MEASURING DIFFERENCES AMONG INSTITUTIONS}

Significant differences in means were found for all criteria between at least two of the three tiers of institutions. Similarities between master-level and bachelor-level institutions are widespread, as are differences between doctoral-level institutions and all others. Data are presented in Table 1.

Doctoral institutions have a mean GMAT score of nearly 100 points higher than master-level institutions, $618\left(23^{\text {rd }}\right.$ percentile) versus 521 ( $56^{\text {th }}$ percentile). A significantly higher proportion of faculty at doctoral-level institutions possess a doctorate degree $(91.6 \%)$ compared with master-level institutions $(84.0 \%)$ or bacheior-level institutions $(82.2 \%)$. The number of full-time faculty at doctoral institutions is more than twice that of master's level institutions, 97.1 versus 46.5. The criteria of greatest difference is size of operating budget, with doctoral institutions possessing a mean budget some $343 \%$ greater than master-level institutions, $\$ 24.25$ million compared to $\$ 5.47$ million. Doctoral institutions offer more than twice as many degree program choices (25.2 versus 10.9) as masterlevel institutions. Master-level institutions offer almost twice as many degree program choices as bachelor-level institutions (10.9 versus 5.7). Doctoral institutions likewise graduate far more students (994) than either master-level institutions (341) or bachelor-level institutions (188). This data is based on degrees awarded between July 1, 2000, and June 30,2001 . Undergraduate tuition is significantly greater at doctoral-level schools $(\$ 14,347$ for the 2002-2003 academic year) than either master-level $(\$ 10,177)$ or bachelor-level $(\$ 10,733)$ institutions. Graduate level tuition is far greater at doctoral-level institutions than master-level institutions, $\$ 31,806$ versus $\$ 14,497$. This is based on estimated total program tuition and fees for students matriculating fall semester, 2002.

These findings indicate quite clearly that three tiers have emerged since mission related standards were implemented over the past eleven years; doctoral level, master's level and baccalaureate level. Differences among the three tiers are significant in many respects beyond just research productivity. The profile of faculty and students, as well as program resources, varies greatly, particularly between the doctoral programs versus both masters and bachelors programs.

\section{METHODOLOGY - FACULTY PERCEPTIONS SURVEY}

But do these differences carry over to differences in faculty perceptions of issues related to their shared AACSB accreditation? Independent variables, for which differences are measured, are faculty rank and highest degree conferred. Differences in perceptions among faculty at different rank may suggest the importance of context. Those at full professor rank most likely have experienced life in academia both before and after the changed standards. Those at the assistant professor rank are more likely to have experienced only the mission-linked standards of recent years.

Differences in perceptions among faculty at institutions whose missions vary greatiy are also measured. The proxy for this independent variable is highest degree conferred at their institution - bachelors, masters, or doctoral.

Issues measured include those numbered three through eleven - see Table 2. There is a body of literature regarding several of these items. Yunker (2000) questioned the validity of assessing teaching quality, noting the inherent subjectivity of student evaluations. He conjectured that AACSB's emphasis on research productivity may be due to this difficulty, and, conversely, the ease with which research output is measured (see items 3 and 4). McKenna, Cotton and Van Auken (1997) suggest the value of formally distinguishing among doctoral, master's and bachelor's programs (item 11). Jantzen (2000) observed that the prestige of accreditation is diminishing with the accreditation of scores of mission-oriented, but not traditionally research-oriented, institutions (item 10). Items 12 - 15 items inciude number of course preparations and course load, measured in terms of actual and what is deemed appropriate.

Ranked faculty at accredited institutions responded to the 15-item survey instrument. The first two items, identifying faculty rank (\# 1) and highest degree conferred at their institution (\#2), are coded 1, 2 or 3 for full professor, associate professor, or assistant professor (\#1); and doctorate, masters, or bachelors for \#2. Items 3 through 11 are coded 1 through 5, one denoting "strongly agree" and five for "strongly disagree." Items 12 through 15 are scaled according to the specific information sought. 


\begin{tabular}{|c|c|c|c|}
\hline \multicolumn{4}{|c|}{$\begin{array}{c}\text { Table } 1 \\
\text { Mean Values and Significance Testing }\end{array}$} \\
\hline Criteria & Tier & Mean & t-statistic $(.05)$ \\
\hline \multirow[t]{2}{*}{ GMAT } & Doctoral $(n=34)$ & 617.620 & \\
\hline & Masters $(n=35)$ & 520.940 & $9.7945^{*}$ \\
\hline \multirow[t]{5}{*}{$\begin{array}{l}\text { Percent of full-time faculty } \\
\text { with doctorate }\end{array}$} & Doctoral & .916 & \\
\hline & Masters & .840 & $4.8671 *$ \\
\hline & Bachelors $(n=10)$ & .822 & \\
\hline & Bachelors vs, masters & & 0.5045 \\
\hline & Bachelors vs. doctoral & & $3.5344^{*}$ \\
\hline \multirow[t]{5}{*}{ Number of full-time faculty } & Doctoral & 97.059 & \\
\hline & Masters & 46.514 & $6.7774^{*}$ \\
\hline & Bachelors & 32.222 & \\
\hline & Bachelors vs. masters & & 1.8604 \\
\hline & Bachelors vs. doctoral & & $4.8318 *$ \\
\hline \multirow[t]{5}{*}{ Size of operating budget } & Doctoral & 24.250 & \\
\hline & Masters & 5.470 & $6.1333^{*}$ \\
\hline & Bacheiors & 3.860 & \\
\hline & Bachelors vs. masters & & 1.5661 \\
\hline & Bachelors vs. doctoral & & $3.3870^{*}$ \\
\hline \multirow[t]{5}{*}{ Number of degree programs } & Doctoral & 25.235 & \\
\hline & Masters & 10.948 & $11.3820^{*}$ \\
\hline & Bachelors & 5.667 & \\
\hline & Bachelors vs, masters & & $3.4242^{*}$ \\
\hline & Bachelors vs. doctoral & & $9.5380^{*}$ \\
\hline \multirow[t]{5}{*}{ Number of graduates } & Doctoral & 994.942 & \\
\hline & Masters & 341.400 & $7.4605 *$ \\
\hline & Bachelors & 188.444 & \\
\hline & Bachelors vs. masters & & $2.3388 *$ \\
\hline & Bachelors vs. doctoral & & $4.9167^{*}$ \\
\hline \multirow[t]{5}{*}{ Undergraduate tuition } & Doctoral & 14,347 & \\
\hline & Masters & 10,177 & $3.0547^{*}$ \\
\hline & Bachelors & 10,733 & \\
\hline & Bachelors vs, masters & & 0.3455 \\
\hline & Bachelors vs, doctoral & & 1.4957 \\
\hline \multirow[t]{2}{*}{ Graduate tuition } & Doctoral & 31,806 & \\
\hline & Masters & 14,497 & $5.6076^{*}$ \\
\hline
\end{tabular}

*Significant difference at the .05 level.

Two hundred and seventy-three completed surveys were received, out of 1,200 sent, for a response rate of $22.75 \%$. Of the 273 complete surveys received, 116 are full professors, 94 are associate professors, and 64 are assistant professors. One hundred and sixteen came from doctoral campuses, 133 from master level programs, and 24 from bachelor level programs.

A two-way analysis of variance was conducted utilizing faculty rank (with three independent variables assistant, associate and full professor) and highest degree conferred (with three independent variables - bachelors, masters, and doctoral level programs\}. Items 3 through 15 comprise the dependent variable. Post hoc testing for significant interaction between the independent variables is tested with the Least Significant Difference (LSD) test. There are two degrees of freedom for each independent variable, rank and highest degree conferred. There are four degrees of freedom for interaction between these variables. A total of 273 degrees of freedom exist. Significance testing is measured at the .05 level. 


\section{FINDINGS - FACULTY PERCEPTIONS SURVEY}

Faculty of all rank and at all three institution levels are generally neutral in their views regarding how AACSB values teaching and research (\# 3 and \#4, Table 2). There is moderate agreement with the statement, "AACSB undervalues service" (\#5). No significant differences are evident. Mean values at all ranks range from 2.50 to 2.73. Mean values at the institutional level ranged from 2.56 to 2.69. There is also moderate agreement, with no significant differences, at all ranks and at all institutional levels $(M=2.45$ to $M=2.80)$ that professionally qualified faculty should have their master's degree from an AACSB accredited institution (\#6). Stronger support is evident for the statement, "Academically qualified faculty should have their doctorate degree from an AACSB accredited institution," with means ranging from 2.24 to 2.40 across faculty rank and institution type (\#7). The post hoc LSD test did find a significant difference between views of associate professors $(M=2.28)$ and assistant professors $(M=1.94)$. There is moderate support at all ranks and at all levels of institutions with the statement, "The AACSB accreditation review process is too strongly controlled by deans" (\#8). Post hoc LSD testing found significantly greater support for this statement from associate professors $(M=2.49)$ than from assistant professors $(M=2.84)$. Strong support, with no significant differences at the .05 level, was found for the statement, "The AACSB accreditation process should include performance reviews of administrators," from all rank levels and institutional levels (\#9). Means range from 2.01 to 2.27. Responses are neutral to slight support for the statement, "The mission-linked accreditation standards have led to a decrease in the quality of new member institutions" (\#10). The range of responses is $\mathrm{M}=3.00$ to $\mathrm{M}=$ 2.77. Strong support exists for the statement, "Accreditation should formally distinguish among, doctoral, master's and bachelor's programs for "branding" purposes" (\#11), with those at bachelor's institutions supporting this at a significantly higher level $(M=1.96)$ that faculty at master's level institutions $(M=2.41)$. In terms of appropriate (\#12) versus actual (\#13) course load, no significant differences are evident among faculty at different rank. But at the institutional level, significant differences are notable, with those at doctoral campuses deeming 4.31 sections an appropriate academic year load, while those at master's and bachelor's levels opined 5.15 and 5.64 sections, respectively. Likewise, actual course load at the doctoral campuses is significantly lower $(M=4.81)$ than at either master's $(M=5.47)$ or bachelor's $(M=6.28)$ programs. In this instance, the master's level programs course load is also significantly lower than the bachelor's level programs. Finally, significant differences are notable regarding the appropriate number of course preparations (\#14) in an academic year at ail levels of institutions, with $\mathrm{M}=2.56$ at doctoral programs, $\mathrm{M}=2.87$ at master's level programs, and $\mathrm{M}=3.36$ at bachelor's level programs. Actual course preparations (\#15) produced significant differences among all institutional levels, as well. Doctoral program faculty had 2.84 preps, versus 3.29 for faculty at master's level programs, versus 3.96 for faculty at bachelor's level campuses.

\begin{tabular}{|c|c|c|c|c|}
\hline & $\begin{array}{l}\text { Mean V } \\
\text { (significe }\end{array}$ & $\begin{array}{c}\text { Tabie } 2 \\
\text { lues and Significance } \mathbf{T} \\
\text { nce below } .05 \text { level high? }\end{array}$ & $\begin{array}{l}\text { esting* } \\
\text { ighted) }\end{array}$ & \\
\hline Item & Faculty Rank - Mean & $\begin{array}{l}\text { Institutional level - } \\
\text { Mean }\end{array}$ & $\begin{array}{l}\text { Main effect f-ratio, } \\
\text { significance }\end{array}$ & $\begin{array}{l}\text { Inter-action f-ratio } \\
\text { and LSD sig. }\end{array}$ \\
\hline $\begin{array}{l}\text { 3. AACSB undervalues } \\
\text { teaching. }\end{array}$ & $\begin{array}{l}\mathrm{P}=3.05, \mathrm{AP}=2.83, \mathrm{ap} \\
=3.00\end{array}$ & Vit & $\mathrm{F}=2.613, \mathrm{p} .=.052$ & $\mathrm{~F}=1.621, \mathrm{p} .=.169$ \\
\hline & 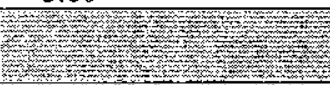 & $\begin{array}{l}\mathrm{D}=2.72, \mathrm{M}=2.86 \\
\mathrm{~B}=3.13\end{array}$ & $\mathrm{~F}=1.693, \mathrm{p} .=.186$ & \\
\hline & 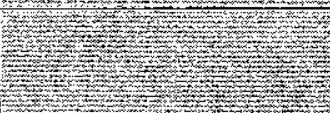 & 10 & $v_{1}$ & $\begin{array}{l}\text { LSD p. }=.068 \text { for } D \\
\& \mathrm{M} ; \mathrm{p}=.055 \text { for } \mathrm{D} \\
\& \mathrm{~B}\end{array}$ \\
\hline $\begin{array}{l}\text { 4. AACSB overvalues } \\
\text { research. }\end{array}$ & $\begin{array}{l}\mathrm{P}=3.08, \mathrm{AP}=2.79, \text { ap } \\
=2.95\end{array}$ & 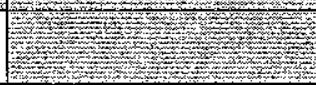 & $\mathrm{F}=2.356, \mathrm{p} .=.072$ & $\mathrm{~F}=2.086, \mathrm{p} .=.204$ \\
\hline & 1 & $\begin{array}{l}\mathrm{D}=3.12, \mathrm{M}=2.86, \\
\mathrm{~B}=2.72\end{array}$ & $\mathrm{~F}=1.644, \mathrm{p} .=.309$ & \\
\hline $\begin{array}{l}\text { 5. AACSB undervalues } \\
\text { service. }\end{array}$ & $\begin{array}{l}\mathrm{P}=2.70, \mathrm{AP}=2.50, \text { ap } \\
=2.73\end{array}$ & S & $\mathrm{F}=1.768, \mathrm{p}=.154$ & $\mathrm{~F}=.884, \mathrm{p} .=.474$ \\
\hline & 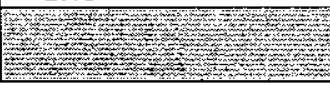 & $\begin{array}{l}\mathrm{D}=2.69, \mathrm{M}=2.6 \mathrm{I}, \\
\mathrm{B}=2.56\end{array}$ & $\mathrm{~F}=.312, \mathrm{p} .=.732$ & \\
\hline
\end{tabular}




\begin{tabular}{|c|c|c|c|c|}
\hline \multirow{2}{*}{$\begin{array}{l}\text { 6. Professionally } \\
\text { qualified faculty should } \\
\text { have their master's } \\
\text { degree from an AACSB } \\
\text { accredited institution. }\end{array}$} & $\begin{array}{l}\mathrm{P}=2.81, \mathrm{AP}=2.79, \text { ap } \\
=2.45\end{array}$ & 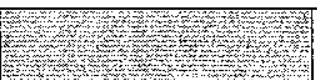 & $\mathrm{F}=1.586, \mathrm{p} .=.154$ & \multirow[t]{2}{*}{$\mathrm{F}=.601, \mathrm{p}=.298$} \\
\hline & 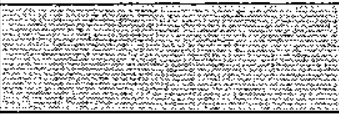 & $\begin{array}{l}\mathrm{D}=2.80, \mathrm{M}=2.65 \\
\mathrm{~B}=2.79\end{array}$ & $\mathrm{~F}=.427, \mathrm{p} .=.212$ & \\
\hline \multirow{2}{*}{$\begin{array}{l}\text { 7. Academically } \\
\text { qualified faculty should } \\
\text { have their doctorate } \\
\text { degree from an AACSB } \\
\text { accredited institution. }\end{array}$} & $\begin{array}{l}\mathrm{P}=2.24, \mathrm{AP}=2.28, \text { ap } \\
=1.94\end{array}$ & 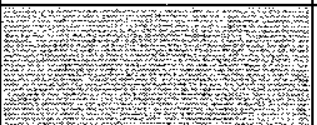 & $\mathrm{F}=3.025, \mathrm{p} .=.050$ & $\mathrm{~F}=2.321, \mathrm{p} .=.057$ \\
\hline & 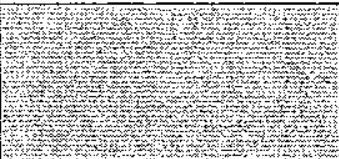 & $\begin{array}{l}\mathrm{D}=2.29, \mathrm{M}=2.07 \\
\mathrm{~B}=2.40\end{array}$ & $\mathrm{~F}=.628, \mathrm{p} .=.535$ & $\begin{array}{l}\text { LSD p. }=.019 \text { for AP } \\
\& \text { ap }\end{array}$ \\
\hline \multirow{2}{*}{$\begin{array}{l}\text { 8. The AACSB } \\
\text { accreditation and } \\
\text { review process is too } \\
\text { strongly controlled by } \\
\text { deans. }\end{array}$} & $\begin{array}{l}\mathrm{P}=2.69, A \mathrm{AP}=2.49, \text { ap } \\
=2.84\end{array}$ & 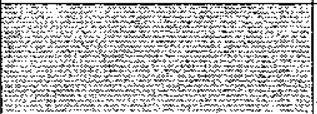 & $\mathrm{F}=1.649, \mathrm{p} .=.178$ & $\mathrm{~F}=.407, \mathrm{p} .=.804$ \\
\hline & \begin{tabular}{|l|l|l|l} 
& 1
\end{tabular} & $\begin{array}{l}\mathrm{D}=2.72, \mathrm{M}=2.65 \\
\mathrm{~B}=2.40\end{array}$ & $\mathrm{~F}=.090, \mathrm{p}_{1}=.914$ & $\begin{array}{l}\mathrm{LSD} \mathrm{p}_{1}=.044 \text { for } \mathrm{AP} \\
\& \text { ap }\end{array}$ \\
\hline \multirow{2}{*}{$\begin{array}{l}\text { 9. The AACSB } \\
\text { accreditation and } \\
\text { review process should } \\
\text { include performance } \\
\text { reviews of } \\
\text { administrators (deans, } \\
\text { associate deans, } \\
\text { assistant deans and } \\
\text { chairs). }\end{array}$} & $\begin{array}{l}\mathrm{FP}=2.01, \mathrm{AP}=2.27 \\
\mathrm{ap}=2.09\end{array}$ & 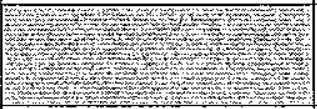 & $\mathrm{F}=.530, \mathrm{p} .=.589$ & $\mathrm{~F}=1.339, \mathrm{p} .=.256$ \\
\hline & 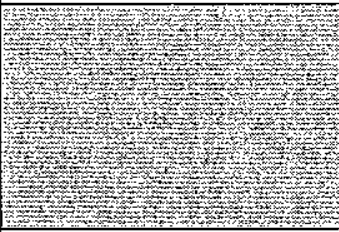 & $\begin{array}{l}\mathrm{D}=2.08, \mathrm{M}=2.15 \\
\mathrm{~B}=2.12\end{array}$ & $\dot{\mathrm{F}}=.030, \mathrm{p} .=.971$ & $\begin{array}{l}\text { LSD p. }=.064 \text { for } P \\
\& A P\end{array}$ \\
\hline \multirow{2}{*}{$\begin{array}{l}\text { 10. The mission- } \\
\text { linked accreditation } \\
\text { standards have led to a } \\
\text { decrease in the quality } \\
\text { of new member } \\
\text { institutions (compared } \\
\text { to pre-1994 standards). }\end{array}$} & $\begin{array}{l}\mathrm{FP}=2.82, \mathrm{AP}=2.81 \\
\mathrm{ap}=2.95\end{array}$ & ats & $\mathrm{F}=.338, \mathrm{p},=.713$ & \multirow[t]{2}{*}{$\mathrm{F}=1.072, \mathrm{p}_{\mathrm{c}}=.371$} \\
\hline & $\begin{array}{lll}1 \\
1\end{array}$ & $\begin{array}{l}\mathrm{D}=2.77, \mathrm{M}=2.88 \\
\mathrm{~B}=3.00\end{array}$ & $F=.552, \mathrm{p} .=.576$ & \\
\hline Item & Faculty Rank - Mean & $\begin{array}{l}\text { Institutional } \\
\text { level - Mean }\end{array}$ & $\begin{array}{l}\text { Main effect f-ratio, } \\
\text { signifi-cance }\end{array}$ & $\begin{array}{l}\text { Inter-action f-ratio } \\
\text { and LSD sig. }\end{array}$ \\
\hline \multirow{2}{*}{$\begin{array}{l}\text { 11. Accreditation } \\
\text { should formally } \\
\text { distinguish among } \\
\text { doctoral, master's and } \\
\text { bachelor's programs for } \\
\text { "branding" purposes. }\end{array}$} & $\begin{array}{l}\mathrm{P}=2.25, \overrightarrow{\mathrm{AP}}=2.30, \text { ap } \\
=2.36\end{array}$ & $\begin{array}{lll}0 & 1\end{array}$ & $\mathrm{~F}=.428, \mathrm{p} .=.654$ & $\mathrm{~F}=.387, \mathrm{p} .=.818$ \\
\hline & W & $\begin{array}{l}\mathrm{D}=2.23, \mathrm{M}=2.41 \\
\mathrm{~B}=1.96\end{array}$ & $\mathrm{~F}=1.284, \mathrm{p} .=.279$ & $\begin{array}{l}\text { LSD p. }=.045 \text { for } M \\
\& B\end{array}$ \\
\hline \multirow{2}{*}{$\begin{array}{l}\text { 12. For an institution of } \\
\text { your stature, what is the } \\
\text { appropriate number of } \\
\text { course sections to be } \\
\text { taught in an academic } \\
\text { year? }\end{array}$} & $\begin{array}{l}\mathrm{P}=4.79, \mathrm{AP}=5.01, \text { ap } \\
=4.66\end{array}$ & bly & $\mathrm{F}=1.073, \mathrm{p} .=.373$ & $\mathrm{~F}=.458, \mathrm{p}=.767$ \\
\hline & $\begin{array}{lll}0 & 1\end{array}$ & $\begin{array}{l}D=4.31, M=5.15 \\
B=5.64\end{array}$ & $\mathrm{~F}=8.881, \mathrm{p}_{1}=.000$ & $\begin{array}{l}\text { LSD } p .=.000 \text { for } D \\
\& M ; p .=.000 \text { for } D \\
\& B\end{array}$ \\
\hline \multirow{2}{*}{$\begin{array}{l}\text { 13. What is the actual } \\
\text { number of course } \\
\text { sections taught in an } \\
\text { academic year at your } \\
\text { institution? }\end{array}$} & $\begin{array}{l}P=5.12, A P=5.55, a p \\
=5.06\end{array}$ & 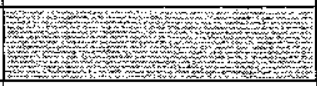 & $\mathrm{F}=1.870, \mathrm{p} .=.156$ & $\mathrm{~F}=.631, \mathrm{p} .=.641$ \\
\hline & r) & $\begin{array}{l}D=4.81, M=5.47 \\
B=6.28\end{array}$ & $\mathrm{~F}=4.727, \mathrm{p} .=.010$ & $\begin{array}{l}\text { LSD p. }=.006 \text { for } \mathrm{D} \\
\& \mathrm{M}, \mathrm{p}=.001 \text { for } \mathrm{D} \\
\& \mathrm{~B}, \mathrm{p} .=.058 \text { for } \mathrm{M} \\
\& \mathrm{~B}\end{array}$ \\
\hline $\begin{array}{l}\text { 14. For an institution of } \\
\text { your stature, what is the }\end{array}$ & $\begin{array}{l}\mathrm{P}=2.76, \mathrm{AP}=2.85, \text { ap } \\
=2.72\end{array}$ & $\frac{1}{15}$ & $\mathrm{~F}=1.563, \mathrm{p} .=.211$ & $\mathrm{~F}=1.720, \mathrm{p} .=.146$ \\
\hline
\end{tabular}




\begin{tabular}{|c|c|c|c|c|}
\hline $\begin{array}{l}\text { appropriate number of } \\
\text { course preparations in } \\
\text { an academic year? }\end{array}$ & W. & $\begin{array}{l}\mathrm{D}=2.56, \mathrm{M}=2.87 \\
\mathrm{~B}=3.36\end{array}$ & $\mathrm{~F}=5.379, \mathrm{p} .=.005$ & $\begin{array}{l}\text { LSD p. }=.012 \text { for } D \\
\& \mathrm{M}, \mathrm{p} .=.000 \text { for } \mathrm{D} \\
\& \mathrm{~B}, \mathrm{p}=.033 \text { for } \mathrm{M} \\
\& \mathrm{~B}\end{array}$ \\
\hline \multirow{2}{*}{$\begin{array}{l}\text { 15. What is the actual } \\
\text { number of course } \\
\text { preparations taught in } \\
\text { an academic year at } \\
\text { your institution? }\end{array}$} & $\begin{array}{l}\mathrm{P}=3.03, \mathrm{AP}=3.41, \text { ap } \\
=3.00\end{array}$ & 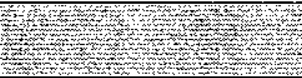 & $\mathrm{F}=4.640, \mathrm{p} .=.010$ & $\mathrm{~F}=3.682, \mathrm{p} .=.006$ \\
\hline & 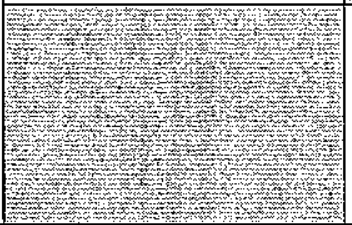 & $\begin{array}{l}\mathrm{D}=2.84, \mathrm{M}=3.29, \\
\mathrm{~B}=3.96\end{array}$ & $\mathrm{~F}=6.185, \mathrm{p} .=.002$ & $\begin{array}{l}\text { LSD p. }=.039 \text { for } \mathrm{P} \\
\& \mathrm{AP}, \mathrm{p} .=.058 \text { for } \\
\mathrm{AP} \text { and ap, } \mathrm{p}=.011 \\
\text { for D \& } \mathrm{M}, \mathrm{p}=.000 \\
\text { for D \& B, } \mathrm{p}=.036 \\
\text { for M \& B }\end{array}$ \\
\hline
\end{tabular}

Notation: $\mathrm{P}=$ full professor, $\mathrm{AP}=$ associate professor, ap = assistant professor; $\mathrm{D}=$ doctoral programs, $\mathrm{M}=$ master level programs, $\mathrm{B}=$ bachelor degree only programs.

\section{CONCLUSIONS}

The breadth and depth of differences among the three tiers of business programs is notable. Doctoral-level institutions are much better financed; have a much larger, and better credentialed faculty; admit students with much higher GMAT scores; charge much higher tuition; offer much more in terms of program options; and graduate far more students than do institutions in the other two tiers. Moreover, the survey of faculty finds doctoral program faculty teach fewer hours of fewer subjects than their colleagues in the other tiers. The survey also indicates faculty support in all tiers for formalizing these differences in terms of some "branding" distinction.

Given these widespread differences in program resources and characteristics, the convergence of faculty perceptions in the three tiers was unexpected. Faculty members at all ranks and at all levels of institutions agree that academically qualified faculty should have their doctorate degree from an AACSB accredited institution. Assistant professors are more strongly supportive of this than associate professors but the support for this statement is universal. There is also widespread support for performance reviews of administrators. Full professors are leading the way in support of this item, perhaps due to their greater experience in observing the management of business programs. Finally, strong support is evident for formally distinguishing among doctoral, master's and bachelor's programs. Interestingly, the strongest support is from bachelor level programs. This is counterintuitive to the supposed "wannabe" motivation for accreditation - modest programs attaining "coattail" benefits of belonging to the same accrediting body that oversees the biggest and the best

Moderate support exists for the assertion that the AACSB review process is too strongly controlled by deans. Assistant professors are actually quite neutral on this, significantly more moderate in their view than associate professors. Moderate support is also evident for the statement that AACSB undervalues service. Knowing the weight of service in the author's workload allocation, five percent, this came as no surprise.

Perhaps the most surprising findings are those with middling vaiues and no significant differences among respondents. There is no support for the notion that mission-linked standards have diminished the quality of new member institutions. This finding challenges the notion that longstanding AACSB members, including most doctoral institutions, countenance misgivings about the caliber of their newer cohorts. One might have also expected some support for this view from senior faculty. But an anticipated dichotomy in responses by rank, with senior faculty (associate and full professors) expressing concern for quality erosion vis-à-vis their junior faculty (assistant professor) counterparts, did not emerge. Similarly, findings among faculty at all ranks and program tiers do not support the view that accreditation undervalues teaching or overvalues research.

The results of the survey instrument suggest many shared beliefs among faculty at all ranks and at all tiers of institutions. While the first part of this research found significant tangible differences among the three tiers, a common identity with AACSB accreditation is evident through the survey results. Further survey research could shed 
light on specific characteristics of this shared identity, as well as features by which branding could best distinguish programs among the three tiers.

\section{REFERENCES}

1. AACSB International web site (2005). 2001-2002 Business School Questionnaire: Key Facts, February 15, 2002.

2. AACSB (2001). Achieving Quality and Continuous Improvement through Self-Evaluation and Peer Review: Standards for Business and Accounting Accreditation.

3. ACBSP web site. Numerous visits, Spring, 2005.

4. Argenti, P. (2000). Branding B-Schools: Reputation Management for MBA Programs. Corporate Reputation Review, 3(2), 171-178.

5. Gioia, Dennis A. and Corley, Kevin G. (2002). Being Good Versus Looking Good: Business School Rankings and the Cicean Transformation From Substance to Image. Academy of Management Learning \& Education. Volume 1, Issue 1, September.

6. gmac.com. (2004). Web site of the Graduate Management Admission Council. Used for GMAT score percentiles.

7. Gordon, R. A. \& Howell, J. E., (1959) Higher Education for Business, New York, Columbia University Press.

8. Jantzen, Robert H. (2000). AACSB Mission-Linked Standards: Effects on the Accreditation Process. Journal of Education for Business, July/August, 343-347.

9. McKenna, John F., Cotton, Chester C., and Van Auken, Stuart (1997). The New AACSB Accreditation Standards: A Prospect of Tiering? Joumal of Organizational Change Management. Vol. 10, No. 6, 491502.

10. Michigan Technical University (2004). http://www.sbea.mtu.edu/sbe/prospectiveStudents/Whysbe.asp.

11. Miller, Eugene (2003). Guide to Graduate Business Schools. Barron's Educational Services, $13^{\text {th }}$ ed.

12. Pierson, F. C., (1959) The Education of American Businessmen, New York, McGraw-Hill.

13. Porter, L.W. and McKibben, L.E. (1988). Management Education and Development: Drift or Thrust into the $21^{\text {st }}$ Century? McGraw-Hill, New York.

14. Ramey, Gerald W. (2001). AACSB: Weathering the Storm. Journal of Organizational Change Management. 8-13.

15. Van Auken, S., Cotton, C.C., McKenna, J.F., and Yeider, R.A. (1993). Future Directions for Business Research: Perspectives of Deans of Accredited Business Schools. Journal of Education for Business. Vol. $68,261-265$.

16. Yunker, James A. (2000). Doing Things the Hard Way - Problems With Mission-Linked AACSB Accreditation Standards and Suggestions for Improvement. Journal of Education for Business. July/August, 348-353. 